\title{
AUDIT COMMITTEE CHARACTERISTICS AND THEIR IMPACT ON INTELLECTUAL CAPITAL DISCLOSURE: A STUDY OF LISTED MANUFACTURING COMPANIES IN SRI LANKA
}

\author{
Nimalathasan Balasundaram \\ Department of Accounting \\ Faculty of Management Studies \& Commerce, \\ University of Jaffna, Sri Lanka \\ E-mail: profnimal@univ.jfn.ac.lk
}

\begin{abstract}
In the today's knowledge based economy, intellectual capital (IC) is considered as a strategic asset which determines the value of the company. Different practices of disclosing IC information in annual reports that do not show the real financial position of a company, is a main problem in Sri Lankan companies. The objective of this study was to find out the impact of audit committee characteristics on Intellectual Capital Disclosure (ICD) of listed companies on the Colombo Stock Exchange (CSE) for a period of five- years from 2012/2013 to 2017/2018. The ICD index comprised of 30 items in terms of Relational Capital Disclosure (RCD), Structural Capital Disclosure (SCD) and Human Capital Disclosure (HCD). The data was analyzed using correlations and regression analysis. Most of the Sri Lankan Listed companies disclosed ICD in text, sentences, pictures, tables and graphs in line with the Global Reporting Initiative (GRI) guidelines in their annual reports. ICD was measured by a disclosure index score. The independent variables comprised various forms of audit committee characteristics: audit committee size, frequency of audit committee meetings and audit committee independence. The study confirms that the size of the audit committee and audit committee meetings are important attributes to explain ICD in Sri Lanka. However, the study found a negative significant relationship between ICD and audit committee independence.
\end{abstract}

Keywords: audit committee independence, audit committee meeting, audit committee size, intellectual capital disclosure

ARTICLE INFO

Article History:

Received: 11 December 2018

Accepted: 3 April 2019

Published: 30 April 2019 


\section{INTRODUCTION}

The audit committee is considered as one of the critical and influential participant of corporate governance. It plays a major role in monitoring, managing disclosure practices and internal controls. As a result, an effective audit committee reduces information asymmetry between management and stakeholders and improves financial reporting processes and levels of corporate disclosure.

The determinants of how much information a company discloses in its annual reports have been the subject of investigation by a number of studies. Hanifa and Cooke (2005) looked at the subject matter in terms of the influence of cultural factors on the quality of corporate governance. The quality of disclosure is very intertwined with the concept of corporate governance, such that the more a company discloses the better the level of transparency which are symptoms of quality corporate governance practices. This is an accounting procedure which involves both human and non-human methodologies and know-how and the interface between these two. The influence of culture on disclosure can thus be seen from the interaction of the human side with the non-human resources and techniques. An adequate financial report disclosure is a common goal of every corporate governance systems.

Today's economy is based on knowledge. Therefore, intellectual capital plays a significant role in the value creation process of an organization. Parker (2007) identified IC accounting research as a major area for further study because IC is critical in the value creation processes of firms (Chaminade \& Roberts, 2003; Habersam \& Piber, 2003) and there is an increased demand for information about IC assets by the capital markets in firm valuation (Lev, 2001; Holland, 2003). Therefore this study aimed to investigate the impact of audit committee characteristics (size of audit committee, frequency of audit committee meetings, audit committee independence) on intellectual capital disclosure (human capital, structural capital and relational capital).

Many researchers have been discussing intellectual capital as a intangible resource in organizations that is a major source of competitive advantage and much empirical research has taken place in the management 
field and capital markets. Nowadays mangers consider knowledge and the ability to create and apply knoweledge is a competitive advatage and is considered as an asset.

Intellectual capital as a set of information resources, which consists of two types of knowledge: explicit knowledge that can be expressed or written, and implicit knowledge that is based on personal experiences and the rules that are used in the development of an organization. It is also defined as a set of skills and mental abilities possessed by a specific group of individuals working in an organization and characterized with a higher cognitive level that leads to innovation, excellence of organizational performance, and achieving a high level of productivity. The main purpose of the disclosure is to provide useful information to users of financial statements that enable them take appropriate decisions. To achieve this goal, disclosures need to be adequate in that the information disclosed in the financial statements should not be misleading, rather they should be fair enough to fully serve all categories without bias.

There is limited understanding of how various corporate governance mechanisms are connected to IC. However, few empirical studies show how corporate governance influences the development of IC in organizations. An audit committee has a specific responsibility, such as monitoring the corporate reporting process of the organization and communicating with external auditors. This study, focusses on the role of the audit committee in enhancing the extent of IC information disclosure.

The study is interested in observing the impact of audit committee characteristics on IC disclosure in manufacturing companies in Sri Lanka. In the Sri Lankan context, we have not found much research concerning audit committee characteristics \& IC disclosure. There are many driving forces, such as globalization, the increased use of information technology, which are pushing Sri Lanka towards becoming a knowledge-based economy. The manufacturing industry not only appears as one of the most knowledgeintensive industries in Sri Lanka but also as a prime mover of economic growth on which other business organizations are dependent.

However, few empirical studies show how corporate governance influences the development of ICD in organizations. But there is limited 
understanding of how various audit committee characteristic mechanisms are connected to ICD.

A number of studies examine the extent of ICD (Brennan, 2001; Beattie, McInnes \& Fearnley, 2004; Beattie \& Thomson, 2007; Li, Pike \& Hanifa, 2008; Striukova Unerman \& Guthrie, 2008). These studies generally show that although IC disclosure is low it has increased over the years. (Li, Mangena \& Pike, 2012) IC disclosure helps reduce investors' uncertainty about the future prospects of an organization and facilitates a more reliable valuation of the organization. (Barth, Kasznik \& McNichols, 2001; Bukh, 2003; Holland, 2003) In this context it is reasonable to expect that the audit committee plays a critical role in enhancing IC disclosure to support investors' valuation processes of a firm.

The main purpose of the study was to examine the significant impact of audit committee characteristics on ICD in listed manufacturing companies in Sri Lanka. To achieve the main objective, the following sub objective is explicated.

1. To identify the relationship between audit committee characteristics and intellectual capital disclosure in listed manufacturing companies in Sri Lanka.

\section{REVIEW OF LITERATURE}

The corporate governance literature is rich with established empirical research on the association between voluntary disclosure and the characteristics of the board of directors. However, limited research has been undertaken to examine the association between ICD and the characteristics of audit committees. Forker (1992) was the first to suggest this association. The author argues that the audit committee is as an effective monitoring mechanism to improve the quality of corporate disclosure and reduce agency costs.

The role of audit committees has developed over the years to meet the challenges of changing business, social and economic environments. Smith (2003) identified the role of audit committees as ensuring that the interests 
of shareholders are properly protected in relation to financial reporting and internal controls. It further recommends that audit committees review the significant financial reporting issues and judgments made in connection with the preparation of the company's financial statements, interim reports, preliminary announcements and related formal statements, such as the operating and financial review and the release of price sensitive information. As such, audit committees can be expected to have a significant impact on value-relevant information disclosure, in which intellectual capital forms a large element in many firms.

Some researchers have shown the significant impact of audit Committee size and IC disclosure. However some other researchers found that larger audit committees are likely to suffer from process losses and diffusion of resposibility (Karamanou \& Vafeas, 2005). But Li et al. (2012) noted that the size of an audit committee has a significant and positive relationship with IC disclosure among UK listed companies. Swadip, Shimul and Sumon (2015) documented that audit committees are important attributes in explaining IC disclosure issues in Bangaladesh. Li (2008) stated the expected positive association between audit committee size and levels of voluntary disclosure. Bambang and Enok (2012) found that there is a significant effect between intellectual capital performance and board governance characteristics such as the competence of board commissioners, proportion of board independence, and size of audit committees.

Li, Mangena and Pike (2012) and Li et al. (2008) found that a positive relationship existed between audit committee characteristics, including the size and frequency of meetings and the extent of ICD. The audit committee and the external auditor should meet regularly, without the executive board members present, to encourage a greater exchange of free and honest views and opinions between both parties.

Some studies found the degree of audit committee independence to be positively associated with financial reporting quality (Mangena \& Tauringana, 2007). Others found that firms with audit committees composed solely of outside directors are less likely to have financial reporting problems (McMullen \& Raghunandan, 1996). 
Nowadays, the importance of IC has become a valuable tool for the development of the key assets in organizations. Research conducted indicate that two-thirds of all American companies are looking for new ways to collect and provide information such as IC. ICD studies were mainly undertaken in the economically developed countries (Abeysekera, 2007). In the context of emerging economies, Pomeroy and Thornton (2008) reported that a positive relationship exists between audit committee and financial reporting quality.

During the last decade, the focus on disclosure and corporate governance has increased gradually in the South Asian countries. Haji and Ghazali (2013) revealed that all corporate governance attributes namely board size, independent directors, board effectiveness and position of the chairman (except family members on the board) were significant in explaining the extent and quality of ICD. Director ownership was found to be consistent in negatively relating to both the extent and quality of ICDs. Government ownership was marginally significant in determining the extent of ICDs. The findings suggest that the revised corporate governance code has a positive impact on ICD at least in the case of large Malaysian listed companies. This implies that regulatory efforts in enhancing corporate governance in Malaysia is starting to prove fruitful in encouraging companies to be involved in more IC investments and hence disclosure.

Taliyang and Jusop (2011) investigated the extent of ICD and the relationship between ICD and corporate governance variables in Malaysian public listed companies. Out of 4 variables tested, only the frequency of audit committee meetings had a significant positive relationship in influencing the level of intellectual capital disclosure. The result also found 72.6 percent of the selected companies disclosed IC in their annual reports. However, the extent of ICD among Malaysian companies is still relatively low at about 3.45 percent. This result revealed that most Malaysian companies are aware about ICD but they are not aware on how to measure, report and disclose this information in their annual report.

In the Sri Lankan context there are no studies focussing on the impact of audit committee characteristics and IC disclosure in the manufacturing sector. Only in a few there are some findings related to the IC disclosure (Abeysekera, 2008; Abeysekera \& Guthrie, 2005) 
Abeysekera and Guthrie (2005) examined the trend of ICD practices in Sri Lanka, surveying the top 30 firms listed on the Colombo Stock Exchange from 1998-1999 and 1999-2000. Their content analysis was based on a checklist of 45 items. The findings indicated that the most reported category was external capital, with individual IC items of each capital category reported by the sample firms in Sri Lanka differing from those in other countries. There is not much research conducted in the manufacturing sector in Sri Lanka. This study thus addresses this absence.

\section{Conceptualization}

In this study the dependent variable is the IC Disclosures Index. The three independent variables which represent audit committee characteristics are size of audit committee, frequency of audit committee meetings and audit committee independence.

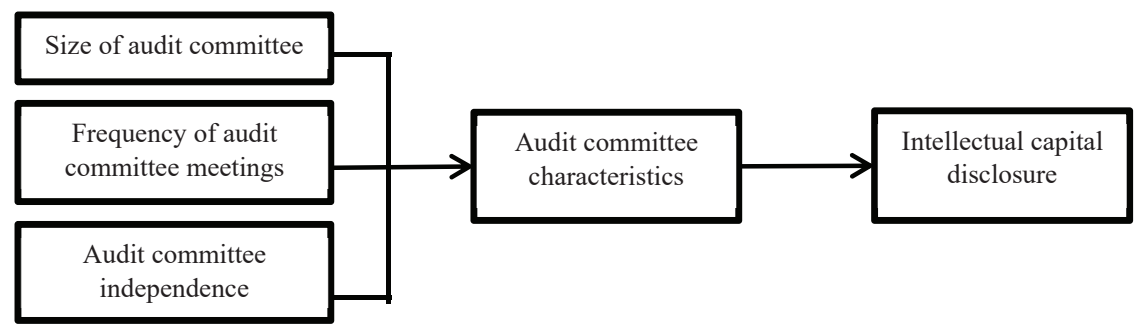

Figure 1: Conceptualization

\section{Hypotheses Formulation}

$\mathbf{H}_{1}$ : Audit committee characteristics have a significant impact on intellectual capital disclosure

\section{METHODOLOGY}

\section{Sampling}

Manufacturing companies listed in the CSE were taken as the population. The CSE is the organization responsible for the operation of the stock market in Sri Lanka. Currently in the year 2017/2018 there are 
companies listed under 20 sectors. The manufacturing sector is a main category from the 20 business sectors in the CSE. Among all of those sectors only the manufacturing sector was selected as the population sample for the study and there are 41 companies listed under the manufacturing sector on the CSE.

As mentioned above the target population of this study includes 41 manufacturing companies. However, the population was chosen and a deductive approach was imposed based on insufficiency of data. Only 28 companies were selected as the sample representing $68 \%$ of the population.

\section{Data Sources}

The research was totally dependent on secondary data, from the annual reports of sample companies for the five financial years. Secondary data for the study were drawn from audited accounts of the companies which were fairly accurate and reliable. Therefore, these data may be considered reliable for the study.

\section{Study Period}

The study attempted to assess intellectual disclosure practices during 2012/2013 - 2017/2018.

\begin{tabular}{ll}
\hline \multicolumn{1}{c}{ Concept } & \multicolumn{1}{c}{ Variables } \\
\hline $\begin{array}{l}\text { Audit committee } \\
\text { characteristics (AC) }\end{array}$ & $\begin{array}{l}\text { Size of audit committee (SAC) } \\
\text { Fudit committee Independence (ACI) }\end{array}$ \\
\hline $\begin{array}{l}\text { Intellectual capital } \\
\text { disclosure (ICD) }\end{array}$ & Suman capital disclosure (HCD) \\
& Relational capital disclosure (RCD) \\
\hline
\end{tabular}




\section{CONCEPT AND VARIABLES OF THE STUDY}

\section{Mode of Analysis}

An econometric statistical package called the STATA was used to analyze the data. In addition to the usual descriptive statistical methods such as the mean, medians and standard deviation were used to analyze the data.

\section{Data Analysis}

\section{Correlation analysis}

Correlation analysis is concerned with describing the strength of relationship between two variables. Therefore, the correlation matrix is advantageous to the researcher to identify initially whether there is a relationship between each variable and relationship between each dependent and independent variable. In this study the correlation analysis was used to find out the relationship between audit committee characteristics and intellectual capital disclosure. This can be described as follows using the following table.

Table 1: Correlation

\begin{tabular}{ccccc} 
Variable & SAC & ACM & ACI & ICD \\
\hline SAC & 1.000 & & & \\
\hline \multirow{2}{*}{ ACM } & $\begin{array}{c}0.236^{* * *} \\
(0.004)\end{array}$ & 1.000 & & \\
\hline \multirow{2}{*}{ ACI } & $\begin{array}{c}-0.178^{* *} \\
(0.035)\end{array}$ & $\begin{array}{c}0.104 \\
(0.217)\end{array}$ & 1.000 & \\
\hline \multirow{2}{*}{ ICD } & $\begin{array}{c}0.580^{* * *} \\
(0.000)\end{array}$ & $\begin{array}{c}0.246^{* * *} \\
(0.003)\end{array}$ & $\begin{array}{c}-0.243^{* * *} \\
(0.003)\end{array}$ & 1.000 \\
\hline
\end{tabular}

** Significant at $5 \%$ level of significance; *** Significant at $1 \%$ level of significance

Variable: SAC-size of audit committee, ACM-audit committee meeting, ACl-audit committee independence, ICD-intellectual capital disclosure

Table 1 shows the relationship between audit committee characteristics and intellectual capital disclosure. There is a significant and positive relationship between SAC and ACM with ICD. The correlation coefficients are 0.580 , and 0.246 respectively. These relationships are significant at the 0.01 level. 
The ACM has a negative relationship with the dependent variable; ICD. The correlation coefficient is -0.243 . There is a significant negative relationship between ACI with ICD, because its $\mathrm{P}$ value is less than 0.05.

\section{Regression analysis}

In this study, the linear regression analysis was used to measure the impact of the independent variables (SAC, ACM, and ACI) on the dependent variable (ICD).

Table 2: Regression Model Summary

\begin{tabular}{cc}
\hline Number of obs & 140 \\
\hline F (3,136) & 27.250 \\
Prob>f & 0.000 \\
R-squared & 0.375 \\
Adj r - squared & 0.361 \\
Root MSE & 8.808 \\
\hline
\end{tabular}

As shown in Table 2 the impact of audit committee characteristic on intellectual capital disclosure is highly significant, because of the Prob $>\mathrm{f}$ is 0.000 showing a significant impact. The $\mathrm{R}$ square value of 0.375 suggest a $37.55 \%$ variability in ICD can be explained by the independent variables. It also indicates that there are some other factors which suggest $62.45 \%$ variability in ICD. In other words, the selected independent variables are able to explain $36.17 \%$ of the variation of the dependent variable. And as shown the conceptual framework and hypothesis are accepted because, the developed model is significant at the Significant F value, 0.000.

Table 3: Regression Model Using Panel Data

\begin{tabular}{lcccccc}
\hline $\begin{array}{l}\text { Intellectual capital } \\
\text { disclosure }\end{array}$ & Coef. & Std. Err & $\mathbf{t}$ & $\mathbf{p}>\mathbf{t}$ & $\mathbf{9 5 \%}$ & $\begin{array}{c}\text { Conf } \\
\text { intervals }\end{array}$ \\
\hline Size of audit committee & 6.65 & 0.92 & 7.25 & 0.000 & 4.83 & 8.46 \\
Audit committee meeting & 1.45 & 0.72 & 2.01 & 0.046 & 0.02 & 2.87 \\
$\begin{array}{l}\text { Audit committee } \\
\text { independence }\end{array}$ & -0.09 & 0.04 & -2.39 & 0.018 & -0.18 & -0.17 \\
Cons & 44.88 & 5.26 & 8.53 & 0.000 & 34.48 & 55.28 \\
\hline
\end{tabular}


Based on the regression results presented in Table-3, the size of the audit committee and audit committee meetings have a positive relationship and significant impact on ICD except for audit committee independence. All audit committee characteristics examined are significant at the $1 \%$ level, but audit committee independence is negatively associated with ICD.

\section{Hypotheses testing}

Correlation analysis and regression analysis were used to test the hypotheses. Those are:

$\mathbf{H}_{1}$ : Audit committee characteristics have a significant impact on intellectual capital disclosure

As shown in Table 2 shows, the R-squared value is 0.375 and the Adjusted R-squared is 0.361 . The R-squared value of 0.375 shows a $37.55 \%$ percentage impact on the independent variable, audit committee size, audit committee meeting, audit committee independence. But when we take into consideration the Adjusted R-squared value for the interpretation of the dependent and independent variable, it shows a $6.17 \%$ percentage impact on the dependent variable by the independent variable. F-value for the model is 27.25 and $\mathrm{P}$-value is 0.000 .In the model, $\mathrm{P}<0.05$, then we can say the model is significant. So, hypothesis H1 is accepted.

$\mathbf{H}_{1 \mathbf{a}}$ : Size of audit committee has a significant impact on the level of ICD

As shown in Table 3, the Coefficient value and t-value for SAC are 6.65 and 7.25 respectively and the P-value for FS is 0.000 . This P-value is lower than 0.05 which provide evidence that the SAC has a $1 \%$ level of significant impact on ICD. So hypothesis H1a is accepted. These findings are consistent with (Suripto, 2012) who also found that the size of the audit committee has a positive effect on Intellectual Capital Performance. It is predicted that larger audit committees can maintain the ICD better.

$\mathbf{H}_{\mathbf{1 b}}$ : Frequency of audit committee meetings has a significant impact on the level of ICD 
The analysis clearly shows the ACM is positively impacted with ICD. Also the impact of ACM is significant because the $P$ value is less than 0.05. So, hypothesis H1b is accepted. Vafeas (1999) also found that the frequency of audit committee meetings has a positive effect on ICD. This is in line with the recommendations of Smith who reported (2003) that a positive relationship exists between level of intellectual capital disclosure and frequency of audit committee meetings.

$\mathbf{H}_{1 \mathbf{c}}$ : Audit committee Independence has a significant impact on level of ICD

According to the analysis ACI has a negative impact at the model. The coefficient correlation value is -0.09 . Also the impact of ACI is significant in the model, because the $\mathrm{P}$ value is less than 0.05 which is 0.018 which provide evidence that is the ACI has a 5\% level of significant impact on ICD So, hypothesis H1c is accepted. The findings of this study are consistent with research conducted by Falikhatun, Aryani and Prabowo (2011).

Table 4: Hypotheses Testing

\begin{tabular}{lcc}
\hline \multicolumn{1}{c}{ Hypotheses } & $\begin{array}{c}\text { Significance } \\
\text { Level }\end{array}$ & Result \\
\hline $\begin{array}{l}\mathrm{H}_{1}: \text { Audit Committee Characteristics have a significant } \\
\text { impact on the level of ICD }\end{array}$ & 0.000 & Accepted \\
\hline $\begin{array}{l}\mathrm{H}_{1 \mathrm{a}}: \text { Size of audit committee has a significant impact } \\
\text { on on the level of ICD }\end{array}$ & 0.000 & Accepted \\
\hline $\begin{array}{l}\mathrm{H}_{1 \mathrm{~b}}: \text { Frequency of audit committee meetings has a } \\
\text { significant impact on the level of ICD }\end{array}$ & 0.046 & Accepted \\
\hline $\begin{array}{l}\mathrm{H}_{1 \mathrm{c}}: \text { Audit committee Independence has a significant } \\
\text { impact on the level of ICD }\end{array}$ & 0.018 & Accepted \\
\hline
\end{tabular}

\section{CONCLUSION \& RECOMMENDATION}

The research findings indicate that audit committee characteristic impact positively on the level of ICD except audit committee independence. Finally, the research concludes that the size of audit committee and audit committee meetings impact on ICD. 
The findings of the study support the Signalling theory. It instructs that signals sent by disclosure of intellectual Capital can enhance the quality of a company. According to this theory, companies have to show their IC in order to satisfy stakeholders' need for information and to signal their value.

\section{REFERENCES}

Abeysekera, I. (2006). The project of intellectual capital disclosure. Journal of Intellectual Capital, 7(1), 61-77.

Abeysekera, I. (2007). Intellectual capital reporting differences between a developed and developing nation. Journal of Intellectual Capital, $8(2), 329-345$.

Abeysekera, I., \& Guthrie. (2005). An empirical investigation of annual reporting trends of intellectual capital in Sri Lanka. Critical Perspectives on Accounting, 16(3), 151-163.

Bambang, M., \& Enok, N. (2012). The Influence of Board Governance Characteristics on Intellectual Capital Performance (Empirical Study on Listed Banks in BEI 2008-2012). Integrative Business Economics, 4(1), 417-430.

Barth, M., Kasznik, R., \& McNichols, M. (2001). Analyst coverage and intangible assets. Journal of Accounting Research, 39(1), 1-34.

Beattie, V., \& Thomson, S. (2007). Lifting the lid on the use of content analysis to investigate intellectual capital disclosures. Accounting Forum, 31(2), 129-163.

Brennan, N. (2001). Reporting intellectual capital in annual reports: Evidence from Ireland. Accounting, Auditing \& Accountability Journal, 14(4), 423-436.

Bukh, P. (2003). Commentary; The relevance of intellectual capital disclosure: A paradox? Accounting, Auditing \& Accountability Journal, 16(1), 41-56. 
Chaminade, C., \& Roberts, H. (2003). What it means is what it does: a comparative analysis of implementing intellectual capital in Norway and Spain. European Accounting Review, 12(4), 733-751.

Falikhatun, Aryani, Y., \& Prabowo, A. (2011). The effect of corporate governance on the intellectual capital disclosure: An empirical study from banking sector in Indonesia. World Review of Business Research, l(4), 66-83.

Forker, J. (1992). Corporate governance and disclosure quality. Accounting \& Business Research, 22(86), 111-124.

Habersam, M., \& Piber, M. (2003). Exploring intellectual capital in hospitals: Two qualitative case studies in Italy and Austria. European Accounting Review, 12(4), 753-779.

Haji, A. A., \& Ghazali, N. A. M. (2013). A longitudinal examination of intellectual capital disclosures and corporate governance attributes in Malaysia. Asian Review of Accounting, 21(1), 27-52.

Haniffa, R., \& Cooke, T. E. (2005). The impact of culture and governance on corporate social reporting. Journal of Accounting and Public Policy, 24, 391-430.

Holland, J. (2003). Intellectual capital and the capital market - Organisation and. Accounting, Auditing \& Accountability Journal, 16(1), 39-48.

Karamanou, I., \& Vafeas, N. (2005). The association between corporate boards, audit committees, and management earnings forecasts: An empirical analysis. Journal of Accounting Research, 43(3), 453-486.

Lev, B. (2001). Intangibles: Management, measurement and reporting. Washington, DC: The Brookings Institution.

Li, J. R. (2008). Intellectual capital disclosure and corporate. Accounting \& Business Research, 38(2), 137-159. 
Li, J., Mangena, M., \& Pike, R. (2012). The effect of audit committee characteristics on intellectual capital discloure. The British Accounting Review, 44, 98-110.

Li, J., Pike, R., \& Haniffa, R. (2008). Intellectual capital disclosure and corporate governance structure in UK firms. Accounting \& Business Research, 38(2), 137-159.

Mangena, M., \& Tauringana, V. (2007). Corporate compliance with nonmandatory best practice statements: the case of the ASB statement on interim reports. European Accounting Review, 16(2), 399-427.

McMullen, D., \& Raghunandan, K. (1996). Enhancing audit committee effectiveness. Journal of Accountancy, 182(2), 79-81.

Parker, L. D. (2007). Financial and external reporting research: the broadening corporate governance challenge. Accounting \& Business Research, 37(1), 39-54.

Smith, R. (2003). Audit commitee: Combined guidence. London: FRC.

Striukova, L., Unerman, J., \& Guthrie, J. (2008). Corporate reporting of intellectual capital. British Accounting Review, 40(4), 297-313.

Suripto, B. (2012). The effect of the implementation of corporate governance in profit management by new chief executive officer. Journal Akuntansi Dan Management, 23(2), 105-117.

Swadip, B., Shimul, C., \& Sumon, B. (2015). Impact of Corporate Governance Attributes on Intellectual Capital Disclosure: Evidence from Listed Banking Companies in Bangladesh. India Finance Conference (IFC). India Institute of Management.

Taliyang, S. M., \& Jusop, M. (2011). Intellectual capital disclosure and corporate governance structure: Evidence in Malaysia. International Journal of Business and Management, 6(12), 109-117.

Vafeas, N. (1999). Board meeting frequency and firm performance. Journal of Financial Economics, 53, 113-142. 